\title{
IMPORTANCE OF KEEPING RECORDS AND ARCHIVES
}

By BESSIE LyON

Recently there was considerable controversy, in the Iowa legislature, over the advisability of keeping old documents and records of early Iowa history. "Why bother with the insignificant details of several generations past? Why not discard these musty old files and fill that space with the records of the real, vibrant activities of today?"

This theory may sound very practical and reasonable, but I wish to raise my voice in protest, against any such possible regime. In justification of my stand, I would call attention to the fact, that some few years ago, a project was started by the government, to find and register the unmarked graves of soldiers, in old cemeteries and other long forgotten places.

The state of Iowa, realizing that much matter of historical value would be found in this work, pushed the matter vigorously. In Hamilton county, Mr. Floyd Pierce carried on this work with much energy and produced excellent results. Being a member of the American Legion, he was especially anxious to locate the graves of soldiers, since the Federal government was providing a metal marker, which would hold a flag, to be used upon the grave of any soldier in any war service in the United States.

In this connection, Mr. Pierce frequently consulted me, and we made several inspection trips to Graceland cemetery; seeing the new markers, each bearing a flag, made me very enthusiastic over the project. No longer should these service men remain unhonored in a neglected grave!

In the course of events, he brought out the fact that my own father, who served, in defense of the north west border, in Co. $\mathbf{C}$ of the Iowa Northern Brigade, should have a metal marker; it is with great satisfaction that 
I find his service recognized, and the little flag that waves over his grave, looks very sweet to me.

Later on, Mr. Pierce said to me, "I have found the name of J. H. Lyon on a list of men who were called "The Iowa Frontier .Guard," who was he?" This was my father's older brother, who had gone to Spirit Lake, with a hastily gathered group, and had endured much hardship, from cold and lack of protection, during the winter of 1858; I began hunting facts, and at $\mathrm{Mr}$. Pierce's suggestion, filled out an application for marble head stone, which the government will furnish for any unmarked soldier's grave, providing the record is authentic.

We felt much pleased over what we had accomplished, and I anxiously awaited an answer to my request. However, months passed, and I finally received this disappointing letter-

Dear Madam: Reference is to the application for a government headstone, to mark the grave of John H. Lyon.

This office regrets to advise you that this application is cancelled, as every effort to identify the military service of the veteran, failed. If at some future date, you discover some pertinent facts, that may enable this office to identify this service, we will be pleased to renew our efforts.

C. C. REYNOLDS

Col. Q. M. Corps, Assistant.

And after all my efforts, that was that!

Now I was sure that my uncle had traveled those weary miles, to the North West border, and that he had given of his strength and energy, to defend young Iowa, when she sorely needed it; he had helped to make this great state safe for civilization, and there he lay in an unmarked grave, because "pertinent facts", were lacking!

This spurred my determination to unearth those facts and secure proof of his services, and thus establish his definite right to governmental recognition; going to our Kendall Young library, I asked where I could find anything about the Iowa Frontier Guard; Miss McMurray 
helped find the files of The ANNALs of IowA, and we located an article in the April issue, of 1913, Vol. XI, No. 1, containing a photostatic copy of the signatures of all those men who enlisted in what was called the "Iowa Frontier Guard." I carefully copied the following roster from this source-

"We, the under signed Officers and Non Commissioned Officers and Privates of the "Iowa Frontier Guard," do hereby acknowledge the receipt from the State of Iowa, of the sum of money, respectively set opposite our names, which appear below, and are attested by a commissioned officer of said company, in full pay for serving the number of days certified to, in the annexed certificate of the captain of said company, being full pay for the services of each man, whose name is hereto attached, from the 22nd of March, to the time of discharge."

\section{ROSTER OF IOWA FRONTIER GUARD}

$\begin{array}{ll}\text { Henry B. Martin } & \text { Wm. T. Somers } \\ \text { Wm. S. Church } & \text { Peter P. Kelly } \\ \text { David S. Jewett } & \text { L. L. Estes } \\ \text { Jonas Ball } & \text { J. W. Knapp } \\ \text { Wm. H. Grayson } & \text { Robert F. Turner } \\ \text { W. S. Defore } & \text { Tyler Grant } \\ \text { Ezra M. Wilcox } & \text { John H. Lyon } \\ \text { Chas. C. Stratton } & \text { Thomas Bonebright } \\ \text { Thos. Mulvaney } & \text { Geo. Olcott } \\ \text { Andrew McPlaetus } & \text { Wm. E. Petton } \\ \text { Franklin R. Mason } & \text { Jacob Knapp } \\ \text { Lemuel McIntosh } & \text { H. C. Hillock } \\ \text { Richard Upton } & \text { A. T. Emiapmsi } \\ \text { G. C. Long } & \text { W. D. Cosslay } \\ \text { A. S. Leonard } & \text { William Donaldson } \\ \text { Wm. B. Harlan } & \text { F. A. Blake } \\ \text { Michael Sweeny } & \text { R. U. Wheelock } \\ \text { W. H. Bates } & \text { J. H. Schuneman } \\ \text { A. Bellville } & \text { C. W. Clark } \\ \text { John W. Davis } & \text { Wm. Barkrusi } \\ \text { Geo. J. Skinner } & \text { Eber Palmer } \\ \text { Wm. W. Funk } & \text { G. W. Royer } \\ & \text { Guernsey Smith }\end{array}$

But however gratifying to my own mind, this information might be, I knew it was not a complete official record, and Washington authorities would not accept it as such. How much money had each received? I must find proof of the sums paid; after thinking things over, I appealed to Curator Ora Williams, of the Iowa State Department of History and Archives, stating the facts 
in the case, and asked if there were not some way of finding that these men had been serving, had been paid and were honorably discharged.

The late Mr. Mahannah, assistant curator, being much intrigued with the story, set to work at once, and after diligent research, produced the desired documentary evidence, to substantiate my claims.

In a very short time I received the following communication, most gratifying to my mind, and a fine testamonial as to the efficiency of the Archives Department:

Jan. 8, 1941.

Miss Bessie Lyon

708 Boone Street, Webster City, Iowa.

Madam: In reply to your request for further information, as to the record of military servies of JOHN H. LYON, will say that I have made some investigation, and find substantially as follows:

The "Iowa Frontier Guard" is the name commonly given to a somewhat irregularly formed organization, for military purposes, organized under the direction of Gov. Ralph P. Lowe, of Iowa, in 1858 for the purpose of protecting settlers on the north western frontier of Iowa. This organization, which did not number more than forty persons, under the direction of Capt. H. P. Martin, was mustered into service for the state, November 22, 1858, and remained in service some five or six months.

The original pay roll sheets for this company, with the signatures of the various members, is on file in the Iowa Department of History and Archives. I have examined these original papers, and find the name of John $\mathrm{H}$. Lyon signed to the various pay rolls and muster rolls and that he was a member during all of the period of service of this company.

The records show that he was mustered in November 22, 1858. The precise date of mustering out is not shown in any of the papers that have been preserved, but from the pay rolls and other evidence, it is plain that the company was discharged on or abont, May 11 or 12, 1859. The papers indicate that for this military service, he received from the state, Two hundred fifty six dollars and fifty cents $(\$ 256.50)$.

There is in the published records of the state, evidence that this company was authorized by the governor, under his authority as Commander-in-Chief of the Army of the State; that the state paid for the services of the men, and that the United States government at a later date, reimbursed the state, at least in 
part, for whatever expenditures were made, on account of this expedition.

As this was an irregular organization, no company number, or regiment number was ever assigned to the same. It was, as I have said, known as the Iowa Frontier Guard. Sometimes it is referred to in history as Captain Martin's company, but there is no doubt but that it performed military service, and that the United States, in the payment of some or all of the expenses thereof, - recognized that service.

I do not know whether this will be sufficient to enable you to complete your very laudable plan to have the grave of $\mathrm{Mr}$. Lyon marked in an official way, but $I$ hope that it will be. If you should find that it is advisable or necessary for me to place this material or information in the form of an affidavit, I will do so. Under the Iowa law, the Curator can certify to facts and they are of standing in our courts.

I would be pleased if you could keep me informed, as to the results of your further work in this line.

Yours truly,

STATE DEPARTMENT OF HISTORY AND ARCHIVES

By Ora Williams, Curator.

I promptly asked for the proffered affidavit, and $\mathrm{Mr}$. Williams sent it, duly notarized, and perfectly official.

As I recall the facts, it was about Feb. 1, 1941, when I sent all this new data to Washington; to my great delight, in about a month I was informed that the record was acceptable, that this record, found in Iowa's Archives, was a sufficiently convincing proof of a soldier's service, to warrant the award of a government head stone, and "What type of marker do you want?"

You may imagine the glee with which I filled out all the necessary forms and how happy I was when the stone came in time for its being placed before Memorial Day. It is a beautiful white stone, of Georgia marble, and it permanently marks the grave of one whose sacrifices had hitherto been unnoted.

The flag on that grave and the white stone are eloquent testimonials that it is of the utmost importance to preserve our records of service men-not only for present reference, but also for all future time.

This is but one instance of the splendid service ren- 
dered by the Department of History and Archives; doubtless hundreds of other cases could be cited were the department desirous of publishing the facts. Therefore, it is with great appreciation of the value of this work, that I say "Keep the History and Archives and let the good work go on."

\section{LOOKING TO RESTORATION OF PROSPERITY}

Iowa representatives of industry have taken the initial steps to assure cooperation in the post-war task of restoring stability and prosperity by the processes that gave to the people of Iowa and the nation their present world leadership. A conference was held in Des Moines March 26, 1943, which may have great historic importance. This meeting was under the direction of Mr. Ralph Budd, who is regional chairman of the Committee for Economic Development, of which Mr. Paul G. Hoffman, of Indiana, is the national chairman. This committee is a voluntary group of business men formed "to assist commerce and industry in preparing to make their full contribution to stability and prosperity through high levels of employment and productivity when peace comes." The committee for Iowa was formed of some fifteen leading business men, with Herbert L. Horton, of Des Moines, as chairman.

The keynote of the conference was the duty of commerce and industry to assure the men in the armed forces that there will be work for them in a free society when the military job is finished, and that such assurance is vitally needed as a contribution to the morale of all concerned in the prosecution of the war.

Mr. Budd, who is president of the Burlington railroad, received his education in Des Moines, and takes special interest in Iowa affairs. All members of the committee are actively engaged in various lines of manufacturing and commerce and are large employers of working men. The plannng by and through this committee is one of the major Iowa activities incidental to the war. 
Copyright of Annals of Iowa is the property of State of Iowa, by \& through the State Historical Society of Iowa and its content may not be copied or emailed to multiple sites or posted to a listserv without the copyright holder's express written permission. However, users may print, download, or email articles for individual use. 